IJTC

Ilomata International Journal of Tax \& Accounting

P-ISSN: 2714-9838; E-ISSN: 2714-9846

\title{
The Influence Of Growth Opportunity And Return On Equity (ROE) Toward Company Capital Structure
}

\section{(Empirical Study of Automotive and Component Sub Sector Companies Listed on the Indonesia Stock Exchange in 2014-2018)}

\author{
Hamdan $^{1}$, Deni Sunaryo ${ }^{2}$ \\ ${ }^{12}$ Faculty of Economics and Business, Serang Raya University \\ Correspondent: hamdanunsera@gmail.com
}

Submitted : June 24, 2020 Revised : July 10,2020 Published : July 30, 2020

\begin{abstract}
This study aims to determine the effect of growth opportunity and return on equity the capital structure of the automotive sub-sector companies and components listed on the Indonesia Stock Exchange (IDX) in 2014-2018. The sample used in this study is the automotive sub-sector companies listed on the Indonesia Stock Exchange (IDX) in 2014-2018. The sampling technique used was purposive sampling method and obtained 8 companies. The data collected is secondary data with the method of documentation through www.idx.com in the form of a company annual report. The analytical tool used for hypothesis testing is SPPS 20. The results of this study are (1) Growth opportunity does not have a significant effect on the company's capital structure. (2) Return on equity has a significant effect on the company's capital structure.
\end{abstract}

Keywords: Company capital structure, Growth Opportunity and Return on equity

\section{INTRODUCTION}

The development of financial management is now so dynamic. This happens along with the high level of business activities and human life in the current era of globalization. This condition causes a variety of discussions about the science of financial management to be so interesting for managers, bureaucrats, and academics and researchers in general are no exception.

The national automotive industry is one of the drivers of the Indonesian economy. The automotive industry has a business chain starting from component manufacturing, vehicle manufacturing itself, distribution network and after-sales service, both formal and public workshops, including parts sales networks throughout Indonesia. In making innovations, funds that are not insignificant are needed, so that to meet these sources of funds, the automotive industry can raise funds from internal and external sources. This is because automotive companies have favorable prospects where transportation is one of the most important needs of the community.

One of the factors that makes a company competitive in the long run is because of the strength of its capital structure. So the decision on the sources of funds used to strengthen the capital structure of a company cannot be seen as a simple decision but has strong implications for what will happen in the future.

Factors that influence fluctuations in capital structure can come from internal and external. The internal factors include depreciation reserves, profits not shared, or retained earnings, etc. 
Meanwhile, external factors. This external funding source is obtained by issuing bonds and various other long-term debt.

Companies with high growth opportunities tend to keep their debt ratios at a low level, this is done to maintain their credit capacity in difficult times. This means that the higher the growth of the company, the lower the debt used. . Thus companies with low growth opportunities will use more long-term debt.

Growth Opportunity for every company is different, this causes different spending decisions taken by financial managers. Companies with high growth opportunity tend to spend investment expenditure with their own capital to avoid the problem of underinvestment, namely not implementing all investment projects that are positive by the company manager (Chen, 2004).

Measuring the net profit gained from using assets. In other words, the higher this ratio, the better the productivity of assets in obtaining net profits.

The company will not be separated from debt in meeting operational financing. Companies that have a large enough debt always expect a large profit as well, because in theory increasing debt will certainly also stimulate an increase in profits from the company.

The greater the level of ability of a company in the greater the rate of return on the net profit of automotive companies and components, it will cause the position of the company's capital owner to be stronger

According to Irham Fahmi (2015: 82) This ratio examines the extent to which a company uses its resources to be able to provide a return on equity. (Irham Fahmi, 2015: 82)

From the above definition, it can be concluded that ROE is one of the factors that influence the fluctuation of a company's capital structure. ROE also serves to determine the company's profit from the rate of return through long-term debt.

According to Hasni Yusrianti (2013) explains that Return On Equity has a significant effect on Capital Structure.

According to Arma Pertiwi (2014) explains that Return On Equity has a significant effect on Capital Structure.

According to Mochamad Yahdi Khairin (2014) explains that Growth Opportunity has a significant effect on the positive direction of the Capital Structure.

Based on the description of previous research evidence and problems in the background above, researchers are interested in conducting research with the title: "the influence of growth opportunity and return on equity on the capital structure of the company in the automotive sub sector and components listed on the Indonesia stock exchange in 2014- 2018 ".

\section{Formulation of the problem}

1. Does Return On Equity (ROE) have a significant effect on the capital structure of automotive sub-sector companies and components listed on the Indonesia Stock Exchange?

2. Does Return On Equity (ROE) have a significant effect on the capital structure of automotive sub-sector companies and components listed on the Indonesia Stock Exchange?

3. Does Growth Opportunity and Return On Equity simultaneously have a significant effect on the capital structure of the automotive sub-sector companies and components listed on the Indonesia Stock Exchange in 2014-2018?

\section{Research purposes}

According to the problem formulation above, the objectives of this study are as follows: 
1. To determine the effect of Growth Opportunity on the capital structure of automotive subsector companies and components listed on the Indonesia Stock Exchange in the 2014-2018 period.

2. To determine the effect of Return On Equity (ROE) on the capital structure of automotive sub sector companies and components listed on the Indonesia Stock Exchange in the 20142018 period.

3. To find out the simultaneous influence of Growth Opportunity and Return On Equity (ROE) on the capital structure of automotive sub-sector companies and components listed on the Indonesia Stock Exchange in the 2014-2018 period.

\section{Theoretical basis}

Another definition of Growth Opportunity or growth opportunity is the change in the total assets of the company (Kartini and Arianto, 2008).

$$
\text { GROWTH }=\frac{\text { Total year assets }(\mathrm{t})-\text { Total year assets }(\mathrm{t}-1)}{\text { Total year assets }(\mathrm{t}-1)}
$$

(Rita Puji Astuti, Faculty of Economics, Pandanaran University Semarang, 2015)

According to Irham Fahmi (2015: 82) Return On Equity (ROE) this ratio examines the extent to which a company uses its resources to be able to provide a return on equity. (Irham Fahmi, 2015: 82)

$$
\mathrm{ROE}=\frac{\text { Net profit }}{\text { Equity }}
$$

(Irham Fahmi, 2016)

According to Irham Fahmi (2014: 53) Capital Structure is a comparison of long-term funding sources that are loans with own capital.

Debt Equity Ratio (DER) = Long-term debt

$$
\text { Owner's equity }
$$

(Hasni Yusrianti, Fund Research Report, Faculty of Economics Unsri 2013)

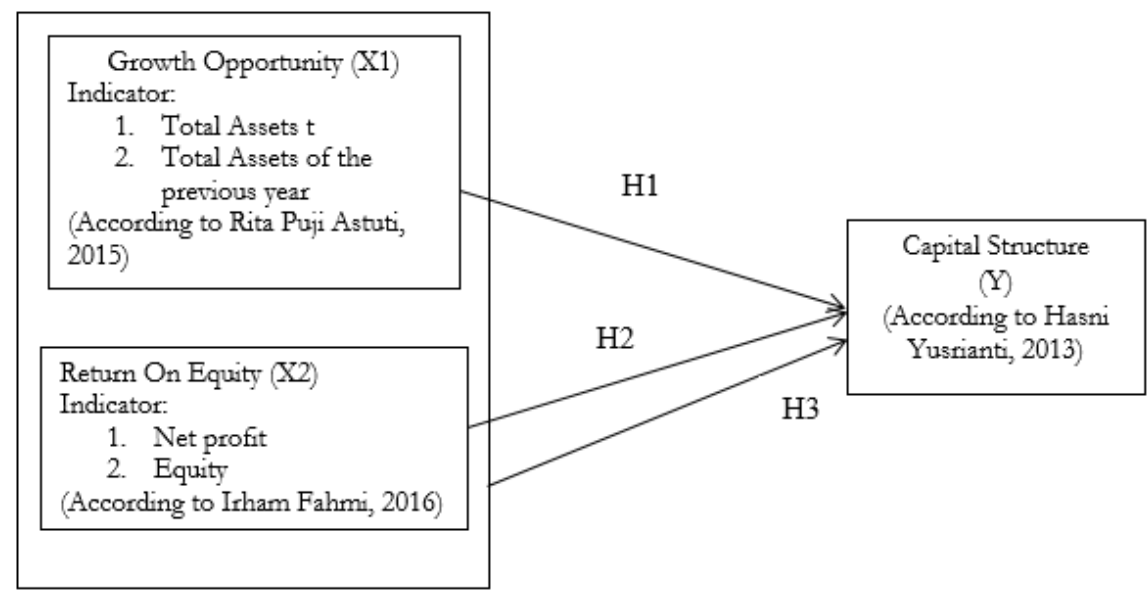

Figure 1

Framework 
The Influence Of Growth Opportunity And Return On Equity (ROE) Toward Company Capital Structure Hamdan \& Sunaryo

\section{HYPOTHESIS}

H1: There is a significant influence between Growth Opportunity (X1) to the Capital Structure (Y) of the Automotive and Components sub-sector manufacturing companies listed on the Indonesia Stock Exchange in 2014-2018.

H2: There is a significant influence between Return on Equity (X2) to the Capital Structure (Y) of the Automotive and Components sub-sector manufacturing companies listed on the Indonesia Stock Exchange in 2014-2018.

H3: There is a significant influence between Growth Opportunity (X1), Return On Equity (X2) to the Capital Structure $(\mathrm{Y})$ of the Automotive and Components sub-sector manufacturing companies listed on the Indonesia Stock Exchange in 2014-2018.

\section{METHOD}

The population used in this study is the automotive and component sub sector companies that have been listed on the Indonesia Stock Exchange in 2014-2018. This study uses a purposive sampling method in determining samples. The criteria applied by researchers in the selection of samples are as follows:

1. Automotive companies listed on the Indonesia Stock Exchange during the period 2014-2018.

2. The Automotive Company publishes financial statements for the fifth year in a row namely 2014-2018.

3. Automotive companies that have complete data during the study for factors examined are growth opportunity, return on equity and capital structure, namely 2014-2018.

Based on these criteria, researchers have determined that there are 8 automotive sub-sector and component companies that meet these criteria. The 8 companies will be used as a research sample with 40 observations.

\section{RESULT AND DISCUSSION}

Table 1.

Descriptive Statistics Testing Results

Descriptive Statistics

\begin{tabular}{|l|r|r|r|r|r|r|r|}
\hline & \multicolumn{1}{|c|}{ N } & Minimum & Maximum & \multicolumn{1}{c|}{ Sum } & \multicolumn{2}{|c|}{ Mean } & Std. Deviation \\
\cline { 2 - 8 } & Statistic & Statistic & \multicolumn{1}{c|}{ Statistic } & \multicolumn{1}{c|}{ Statistic } & \multicolumn{1}{c|}{ Statistic } & \multicolumn{1}{c|}{ Std. Error } & Statistic \\
\hline GROWTH & 40 & 1.00 & 35.00 & 227.00 & 5.6750 & 1.24827 & 7.89478 \\
ROE & 40 & 1.00 & 12412.00 & 54368.00 & 1359.2000 & 369.22681 & 2335.19538 \\
DER & 40 & 2.00 & 826.00 & 3429.00 & 85.7250 & 21.31579 & 134.81288 \\
Valid N (listwise) & 40 & & & & & & \\
\hline
\end{tabular}

Source: results of data processing in SPSS 20

Table 1 presents statistics from the study sample that illustrates the minimum, maximum, average and standard deviation of each variable. $\mathrm{N}$ value indicates the amount of data used in this study, namely the length of the year period according to the data included in the criteria.

The normality test results show the point spreads around the diagonal line and follows the direction of the diagonal line, then the regression model meets the normality assumption. 
The Influence Of Growth Opportunity And Return On Equity (ROE) Toward Company Capital Structure Hamdan \& Sunaryo

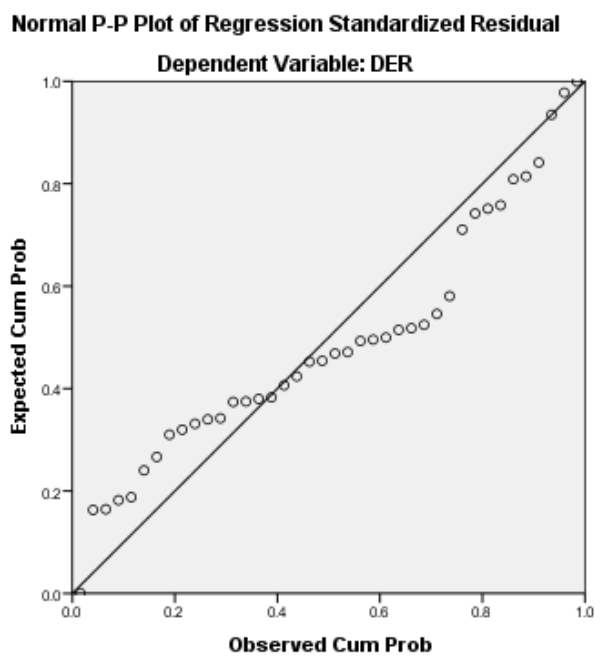

Figure 2.

Normality Test Results

Source: results of data processing in SPSS 20

Table 2.

Normality test

One-Sample Kolmogorov-Smirnov Test

\begin{tabular}{|ll|r|}
\hline & & $\begin{array}{r}\text { Unstandardiz } \\
\text { ed Residual }\end{array}$ \\
\hline $\mathrm{N}$ & & 40 \\
Normal Parameters & Mean & $0 \mathrm{E}-7$ \\
Most Extreme Differences & Std. Deviation & Absolute \\
& Positive & .178 \\
& Negative & .178 \\
Kolmogorov-Smirnov Z & & -.132 \\
Asymp. Sig. (2-tailed) & & 1.126 \\
\end{tabular}

a. Test distribution is Normal.

b. Calculated from data.

Source: results of data processing in SPSS 20

The results of the normality test show table 2 can be seen in the column of significance kolmogorov-smirnov Asymp.Sig (2-tailed) values show above 0.05 . That means that the regression model is said to be normal.

Table 3.

Multicollinearity Test Results

\begin{tabular}{|c|c|c|c|c|c|c|c|c|}
\hline \multicolumn{9}{|c|}{ Coefficients $^{a}$} \\
\hline & & \multicolumn{2}{|c|}{ Unstandardized Coefficients } & $\begin{array}{c}\text { Standardized } \\
\text { Coefficients }\end{array}$ & \multirow[b]{2}{*}{ t } & \multirow[b]{2}{*}{ Sig. } & \multicolumn{2}{|c|}{ Collinearity Statistics } \\
\hline \multicolumn{2}{|c|}{ Model } & B & Std. Error & Beta & & & Tolerance & VIF \\
\hline \multirow[t]{3}{*}{1} & (Constant) & 29.712 & 21.577 & & 1.377 & 177 & & \\
\hline & GROWTH & 2.007 & 2.444 & .118 & .821 & .417 & .794 & 1.259 \\
\hline & ROE & .033 & .008 & .569 & 3.973 & .000 & .794 & 1.259 \\
\hline
\end{tabular}

Source: results of data processing in SPSS 20 
Based on the table above, it can be seen that all independent variables, namely Growth Opportunity and Return On Equity (ROE) have a tolerance value greater than 0.10 and a VIF value smaller than 10 . This means that there is no multicollinearity, so good data is used in the regression model.

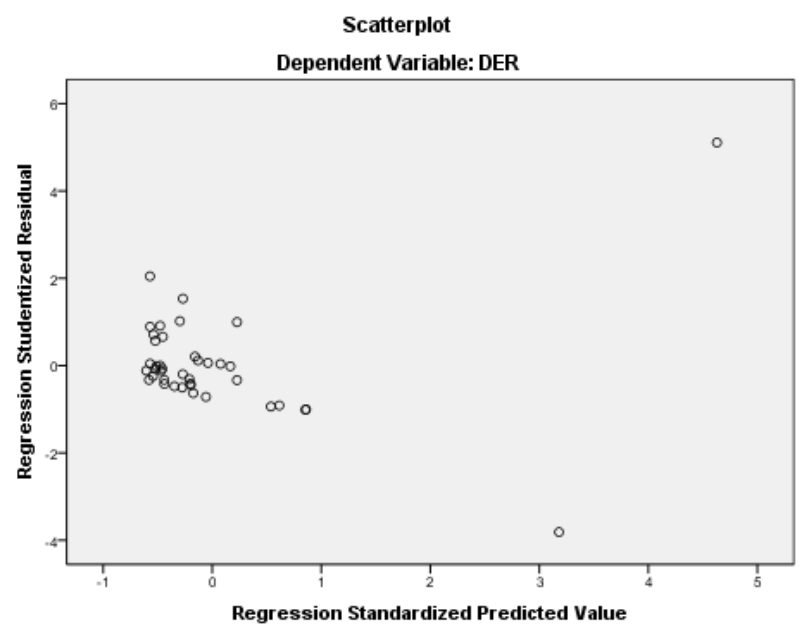

Figure 3

Heteroscedasticity Test Results

Source: results of data processing in SPSS 20

Based on the picture above, it can be seen that the residual data in both regression models spreads above and below the 0 point and does not form a specific pattern. So it can be concluded that in this study there were no symptoms of heteroscedasticity.

Table 4.

Autocorrelation Test Results

\begin{tabular}{|c|c|c|c|c|c|}
\hline \multicolumn{6}{|c|}{ Model Summary } \\
\hline Model & $\mathrm{R}$ & R Square & $\begin{array}{c}\text { Adjusted R } \\
\text { Square } \\
\end{array}$ & $\begin{array}{l}\text { Std. Error of } \\
\text { the Estimate }\end{array}$ & $\begin{array}{l}\text { Durbin- } \\
\text { Watson }\end{array}$ \\
\hline 1 & $.631^{\mathrm{a}}$ & .398 & .365 & 107.40000 & 1.944 \\
\hline
\end{tabular}

a. Predictors: (Constant), ROE, GROWTH

b. Dependent Variable: DER

Source: results of data processing in SPSS 20

Based on table 4. above shows that the value of Durbin-Watson is 1.944. This means that in this study the number is located between -2 and +2 which means there is no autocorrelation in the regression model used.

Table 5.

Multiple Linear Regression Test Results Coefficients $^{\text {a }}$

\begin{tabular}{|c|c|c|c|c|c|c|c|c|}
\hline \multirow{2}{*}{\multicolumn{2}{|c|}{ Model }} & \multicolumn{2}{|c|}{ Unstandardized Coefficients } & \multirow{2}{*}{$\begin{array}{c}\begin{array}{c}\text { Standardized } \\
\text { Coefficients }\end{array} \\
\text { Beta }\end{array}$} & \multirow[b]{2}{*}{$t$} & \multirow[b]{2}{*}{ Sig. } & \multicolumn{2}{|c|}{ Collinearity Statistics } \\
\hline & & B & Std. Error & & & & Tolerance & VIF \\
\hline \multirow[t]{3}{*}{1} & (Constant) & 29.712 & 21.577 & & 1.377 & .177 & & \\
\hline & GROWTH & 2.007 & 2.444 & .118 & .821 & .417 & .794 & 1.259 \\
\hline & ROE & .033 & .008 & .569 & 3.973 & .000 & .794 & 1.259 \\
\hline
\end{tabular}

a. Dependent Variable: DER

Source: results of data processing in SPSS 20 
Based on the above table, the regression equation can be arranged:

$$
\mathrm{Y}=\mathrm{a}+\mathrm{b} 1 \mathrm{X} 1+\mathrm{b} 2 \mathrm{X} 2+\mathrm{e} \ldots \ldots \ldots . . . .
$$

Capital Structure $=29,712-$ Growth $(2,007)-\operatorname{ROE}(0,033)$

Constant Coefficient $(\mathrm{Y})$ of 29,712; meaning that if there is no Growth Opportunity and ROE then the beta value of 29.712. That is if the amount of Growth Opportunity and ROE is equal to zero, then the Capital Structure is 29.712. Regression Coefficient (X1) of 2.007, each increase in the value of Growth Opportunity increases by one unit, then it will be followed by a Capital Structure value of 2.007. Regression Coefficient (X2) of 0.033 means that every ROE addition of one unit will be followed by a Capital Structure value of 0.033 .

Table 6.

Results of the Determination Coefficient Analysis

Model Summary

\begin{tabular}{|l|c|r|r|r|r|}
\hline Model & $R$ & R Square & $\begin{array}{c}\text { Adjusted R } \\
\text { Square }\end{array}$ & $\begin{array}{c}\text { Std. Error of } \\
\text { the Estimate }\end{array}$ & $\begin{array}{c}\text { Durbin- } \\
\text { Watson }\end{array}$ \\
\hline 1 & $.631^{\mathrm{a}}$ & .398 & .365 & 107.40000 & 1.944 \\
\hline
\end{tabular}

a. Predictors: (Constant), ROE, GROWTH

b. Dependent Variable: DER

Source: results of data processing in SPSS 20

Based on table 6 above produces an adjusted $\mathrm{R}$ square value of $0.365(36.5 \%)$. This $\mathrm{R}$ square value indicates the contribution of the independent variable to the dependent variable is $36.5 \%$, while the remaining $63.5 \%$ is influenced by other variables not included with the studied variables such as Liquidity, Firm Size, Business Risk and others.

Table 7.

t-test

Coefficients $^{a}$

\begin{tabular}{|c|c|c|c|c|c|c|c|c|}
\hline \multirow{2}{*}{\multicolumn{2}{|c|}{ Model }} & \multicolumn{2}{|c|}{ Unstandardized Coefficients } & \multirow{2}{*}{$\begin{array}{c}\begin{array}{c}\text { Standardized } \\
\text { Coefficients }\end{array} \\
\text { Beta }\end{array}$} & \multirow[b]{2}{*}{$t$} & \multirow[b]{2}{*}{ Sig. } & \multicolumn{2}{|c|}{ Collinearity Statistics } \\
\hline & & $\mathrm{B}$ & Std. Error & & & & Tolerance & VIF \\
\hline \multirow[t]{3}{*}{1} & (Constant) & 29.712 & 21.577 & & 1.377 & .177 & & \\
\hline & GROWTH & 2.007 & 2.444 & .118 & .821 & .417 & .794 & 1.259 \\
\hline & ROE & .033 & .008 & .569 & 3.973 & .000 & .794 & 1.259 \\
\hline
\end{tabular}

Source: results of data processing in SPSS 20

Based on the results of the above calculation, it is known that in the first equation, the value of $t$ ( $t$-count) obtained in regression shows the effect of partially independent variables on the dependent variable. Regression results are known that the magnitude of the value of the Growth Opportunity variable is 0.821 while the value of the table is 2.0261 because tcount $<$ ttable or a significance level of $0.417>0.05$ then $\mathrm{H} 1$ is rejected, which means Growth Opportunity has no significant effect on the company's capital structure.

From the regression results it is known that the value of the t-count variable Return On Equity (ROE) is 3.973 while the value of $t$-table is 2.0261 because tcount $>t$-table or a significance level of $0,000<0.05$ then $\mathrm{H} 2$ is accepted, which means Return on Equity (ROE) has a significant effect on the company's capital structure of the company. 
Table 8.

F test

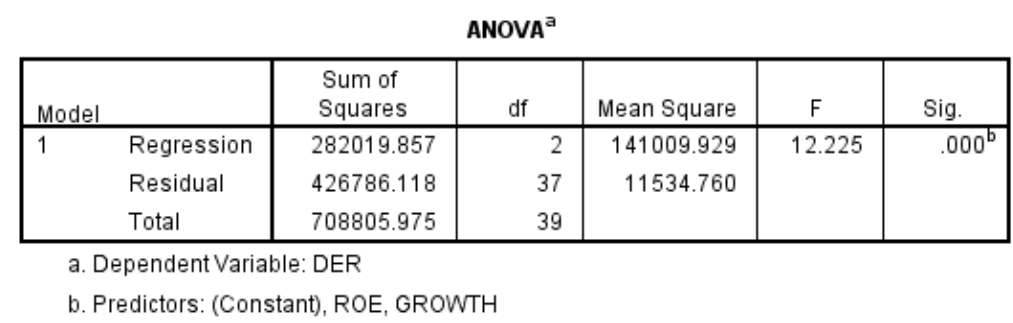

Source: results of data processing in SPSS 20

From the calculation results obtained, the value of Fcount in the amount of 12,225. Next, compare Fcount with Ftable. Where if Fcount $>$ Ftable, simultaneously the independent variables significantly influence the dependent variable. Using $\alpha=0.05$, a $F$ value of 3.25 was obtained.

So the value of Fcount is 12.225 and Ftable 3.25 means that Fcount $>$ Ftable (12.225> 3.25 ) or a significance value of $0.000<0.05$. Thus all the independent variables in this study in the form of Growth Opportunity and Return On Equity (ROE) together (simultaneously) have a significant effect on the company's capital structure.

\section{CONCLUSION}

This study aims to determine the effect of Growth Opportunity and Return On Equity (ROE) on the capital structure of automotive sub-sector companies and components listed on the Indonesia Stock Exchange (IDX) during 2014-2018. Based on the analysis of the data that has been done, the researcher will give some conclusions as follows: (1) Based on the test results Growth Opportunity variable with a significant level of $0.417>0.05$, so partially the Growth Opportunity variable does not significantly influence the company's Capital Structure; and (2) Based on the results of the t-test variable Return On Equity (ROE) with a significant level of 0,000 $<0.05$, so partially the Return On Equity variable (ROE has a significant effect on the company's capital structure.

Bound to the limitations of the research previously mentioned, here are some suggestions for further research: (1) It is expected that researchers who will conduct similar research can add or replace other variables such as Liquidity, Firm Risk, and others. Future studies can also replace different research objects; (2) The next researcher can use company size in terms of sales growth.; and (3) For companies, the current economic condition turns out to be very dependent on funding issues, especially in the case of companies that are growing constantly dealing with the issue of capital increase which aims to develop production scale and expand markets to achieve more efficient operational levels. The company must determine how much debt to capital to the company in order to achieve better financial ratios to finance the company's operational activities.

\section{REFERENCE}

Ana, Safitri (2017). Pengaruh Ukuran Perusahaan, Pertumbuhan Asset, Profitabilitas dan Pertumbuhan Penjualan terhadap Struktur Modal pada Perusahaan Cosmetics and Household yang Terdafar di Bursa Efek Indonesia tahun 2011-2014. Jurnal Akuntansi dan Pajak Fakultas Ekonomi Universitas Islam Batik Surakarta, Vol.18, No.01 
Astuti, Rita Puji (2015). Pengaruh Profitabilitas, Size, Growth Opportunity, Liquiditas dan Struktur Aktiva terhadap Struktur Modal pada Perusahaan Perbankan di Bursa Efek Indonesia periode 2009-2013. Fakultas Ekonomi Universitas Pandanaran, Semarang.

Fahmi, Irham. (2015). Pengantar Manajemen Keuangan. Bandung : Penerbit Alfabeta.

Husnan, Suad. (2006). Dasar-Dasar Manajemen Kenangan. Yogyakarta. Penerbit UPP STIM YKPN.

Hernando, Nico (2016). "Pengaruh Tingkat Profitabilitas dan Pertumbuhan Perusahaan Terhadap Nilai Perusahaan dengan Struktur Modal sebagai variabel Mediating Pada Perusahaan Manufaktur di Bursa Efek Indonesia tahun 2010-2014”. Jurnal Bisnis dan Manajemen, Vol.52

Indra, Arief, et all (2016). "Pengaruh Firm Size, Growth Opportunity, Profitability, Busines Risk, Effective Tax Rate, Asset Tangibility, Firm Age dan Liquidity terhadap Struktur Modal pada Perusahaan Property dan Realestate di Bursa Efek Indonesia periode 2009-2014”. Jurnal Administrasi Bisnis Fakultas Ilmu Administrasi Universitas Brawijaya Malang, Vol.31, No.1

Khairin, Yahdi (2014). "Pengaruh Growth Opportunity, Profitabiltas, Fixed Asset

Ratio dan Risiko Pasar Terhadap Struktur Modal Perusahaan Property dan Realestate Di Bursa Efek Indonesia tahun 2010-2012”. Fakultas Ekonomika dan Bisnis, Universitas Diponegoro Semarang

Lukman, Syamsudin. (2007). Manajemen Keuangan Perusahaan. Jakarta : Penerbit Raja Grafindo Persada.

Najib, Mohammad. (2015). Manajemen Keuangan. Bandung : Penerbit CV Pustaka Setia.

Pertiwi, Arma (2014). “Analisis Pengaruh Ukuran Perusahaan, Profitabilita dan Kepemilikan Manajerial terhadap Struktur Modal pada Perusahaan Pertambangan yang terdaftar di Bursa Efek Indonesia periode 2009-2012”. Fakultas Ekonomi dan Bisnis Universitas Dipenogoro, Semarang.

Santoso, Yuswanandre (2016). "Pengaruh Profitabilitas, Ukuran Perusahaan, Struktur Aktiva, Likuiditas dan Growth Opportunity terhadap Struktur Modal pada Perusahaan Manufaktur yang terdaftar di Bursa Efek Indonesia (BEI) periode 2010-2015”. Jurnal Profita Edisi 4 Fakultas Ekonomi, Universitas Negeri Yogyakarta

Sri Hermuningsih (2013). Pengaruh Profitabilitas, Growth Opportunity, Struktur Modal Terhadap Nilai Perusahaan Pada Perusahaan Publik di Indonesia. Jurnal. Buletin Ekonomi Moneter dan Perbankan.

Sugiyono. 2017. Metode Penelitian Kuantitatif, kualitatif dan R\&D. bandung : Penerbit Alfabeta.

Yunitri, Made (2018). "Pengaruh Tingkat Pertumbuhan, Struktur Aktiva, Profitabilitas dan Likuiditas terhadap Struktur Modal Pada Perusahaan Pertambangan yang Terdaftar Di Bursa Efek Indonesia tahun 2012-2015”. E-Jurnal Manajemen Unud, Vol.07, No.3

Yusrianti, Hasni (2013). "Pengaruh Tingkat Profitabilitas, Struktur Asset, dan Growth Opportunity terhadap Struktur Modal pada Perusahaan Manufaktur yang telah Go Public di Bursa Efek Indonesia (BEI) periode 2008-2012”. Laporan Penelitian Fakultas Ekonomi Unsri.

Yeni, Ni Putu (2015). "Pengaruh Profitabilitas dan Struktur Asset terhadap Struktur Modal pada Perusahaan Property dan Realestate yang terdaftar di Bursa Efek Indonesia periode 20112013”. Jurnal Manajemen Universitas Mahasaraswati, Denpasar, Vol.5 No.2 